Marquette University

e-Publications@Marquette

9-1-2005

\title{
God and the Global Economy: Religion and Attitudes Towards Trade and Immigration in the United States
}

Joseph P.Daniels

Marquette University, joseph.daniels@marquette.edu

Marc von der Ruhr

St. Norbert College

Accepted version. Socio-Economic Review, Vol. 3, No. 3 (September 2005): 467-489. DOI. This is a pre-copy-editing, author-produced PDF of an article accepted for publication in Socio-Economic

Review following peer review. The definitive publisher-authenticated version is available online at this DOI. 


\section{God and the global economy: religion and attitudes towards trade and immigration in the United States}

By Joseph P. Daniels ${ }^{\dagger}$ and Marc von der Ruhr ${ }^{\ddagger}$

Using the results of a national identity survey, we test the impact of religious affiliation on trade and immigration-policy preferences of US residents while controlling for individual level of skill, political ideology and other important demographic characteristics. Our results show that religion is an important determinant of international-policy preferences as individuals who are pre-Vatican II Catholic or members of a fundamentalist Protestant denomination are more likely to prefer policies that restrict imports and immigration. Religiosity, in contrast, has a separate effect of moderating attitudes towards immigration. In addition, we find evidence of denominational effects among African Americans in that members of fundamentalist denominations tend to favour policies that restrict imports while others do not, implying that statistical results commonly attributed to racial effects may actually be a religion effect.

\section{Introduction}

Since Max Weber's study of the Protestant ethic, scholars from a wide variety of academic disciplines have debated the effects of religion on a nation's economic performance. Recently there is a renewed attention to the relationship between religion, international relations, openness and economic growth [for summaries of the literature see Welch and Mueller (2001), Dark (2000), lannoccone (1998) and Smith and Sawkins (1998)]. Grossman and Helpman (2000) make clear the importance of understanding societal ideas and preferences and the role of special interest groups in shaping international policy. Yet, Philpott (2002) argues that until 11 September, international political-economy scholars have paid relatively little attention to the role of religion. Nonetheless, a recent study on American views of globalization (PIPA, 2000), however, shows that views on globalization are affected by moral beliefs and varying degrees of

confidence in a market-based system. ${ }^{1}$ Some also take the view that globalization is a threat to religious beliefs in that globalization leads to 'foreign' values supplanting local ones (Foreign Policy, 2004).

In this study, we examine the relationship between an individual's affiliation with a particular religious denomination and their preferences over trade and immigration policies. In a manner similar to Milner (1988), we focus on individual attitudes and not policymakers' actions

Daniels, von der Ruhr 1 
and, therefore, do not account completely for trade and immigration policy outcomes. Implicitly, we follow Guiso et al. (2003) who argue that religious beliefs are low frequency variables_based on religious teachings and conditioned by the cultural environment of the religion-that affect adherent attitudes towards the economic system. We, therefore, hypothesize that fundamentalist denominations, on the one hand, are networks that generate Putnam's (2003, p. 23) bonding social capital—or strong in-group loyalty—while generating antagonism towards those outside the fundamentalist network. Liberal and moderate Protestant denominations, on the other hand, are bridging networks that are less threatened by modernization, generate relatively more outward trust, and are less likely to be antagonistic towards outsiders. This view is perhaps best represented by a recent Financial Times article (Financial Times, 14 May 2004, p. 4) on trade and the US economy in which a textile worker is quoted as saying:

I am very worried about the ways things are going. The jobs are disappearing. We need to get back to a biblical perspective of taking care of our own.

Although trade and immigration policy decisions do not hinge on public opinion alone, they are an important element in international policymaking (see Graham, 1994 for a forceful argument). We argue that religious affiliation is an important and often neglected force that shapes and reinforces these attitudes.

Using data on the 1367 International Social Survey Policy respondents of the 1996 General Social Survey, we estimate ordered probit models of the responses to questions as to whether the United States should restrict imports and whether the United States should increase or reduce immigration. While testing denominational and religiosity effects, we control for citizenship, gender, social class, resident of south census region, race, union membership, political ideology, education and whether the respondent is employed in a sector with a comparative advantage or disadvantage.

Our empirical results, in general, show that religious affiliation is indeed a statistically significant determinant of trade and immigration-policy preferences. Specifically, individuals who are members of a fundamentalist Protestant denomination or pre-Vatican II Catholic are more likely to favour policies that restrict imports and immigration. Regarding Catholics, however, we show that there is a statistically significant difference in the attitudes of pre-Vatican II Catholics and post-Vatican II Catholics. Likewise, there is evidence that African Americans affiliated with fundamentalist denominations are more likely to favour policies that restrict imports while African Americans not affiliated with a fundamentalist denomination do not. The heterogeneity of our results shows the importance of disaggregating Protestant denominations and controlling for 
changes in attitudes that occurred among older and younger Catholics. Consequently, previous research that ignored the role of religion may have overstated the importance of other factors such as race and region.

The remainder of the paper is organized as follows. In Section 2 we discuss the economic consequences of religious participation and why religion might matter for international-policy preferences. In Section 3 we outline recent models of individual preferences for trade and immigration policies. In Section 4 we describe the data used in the study. In Section 5 we explain our econometric approach and provide results. Finally, we offer a conclusion and suggestions for further research in Section 6.

\section{Religious affiliation, participation and attitudes towards international policies}

In an extensive survey, lannaccone (1998) separates studies of economics and religion into three categories. The first line of research deals with the micro-foundations of religious participation, the second addresses the economic consequences or outcomes of religious participation, while the third line of research invokes religious teachings to critique economic policies. This study is in keeping with the second area of research. The reader is referred to lannaccone for a comprehensive review of the literature in all three areas.

\subsection{Religion and economic performance}

There are a number of prominent empirical studies of the economic consequences of religious affiliation on economic activity and growth in the literature. Because of space considerations, we highlight but a few relevant papers here. The most recent studies on the link between religious participation and economic outcomes include Guiso et al. (2003), who employ survey data covering 66 countries. The authors find that religion promotes the development of positive attitudes towards cooperation and the rule of law and government that are conducive to economic growth. In contrast, they also find that religious individuals are less tolerant of women working and more racist. By controlling for the dominant religion in each nation, they show that these effects differ across denominations.

In a similar manner, Barro and McCleary (2003) use survey data covering 59 countries and find that economic growth is positively affected by religious beliefs, but negatively by church attendance even while controlling for possible reverse causation. In a similar manner, Mehanna (2002) finds that countries whose dominant faith is Protestant tend to be more open, as measured by imports as a percentage of GDP, than Catholic or Muslim nations. 


\subsection{Why would religion matter for trade and immigration?}

According to religion and sociology scholars such as Ammerman (1991), Marsden (1991) and Tamney (2002), modernization, industrialization and urbanization of the early twentieth century challenged both the moral certainty and social dominance of traditional Protestantism. The fundamentalist movement was, therefore, a religious-based social movement counteracting encroaching secularism and modernization. Coreno (2002, p. 337) argues that '...fundamentalists often form small interconnected independent denominations in the hope of protecting a quarantined traditionalist culture inside a network of church-based institutions. They nourish these enclave communities by separating themselves as much as possible from mainline churches in particular, and secular culture in general'. He adds that southern fundamentalist denominations, in particular, support a stronger sense of separatism. Moderate and liberal Protestants, in contrast, are less threatened by secular society and tend to thrive more in a modern world. They are also less concerned with biblical inerrancy and tend to treat religious beliefs as more personal and private. Further, moderate or mainline denominations tend to relate more inclusively with other denominations and engage more in ecumenical activities.

In regard to Catholics, Putnam et al. (1993) argue that the hierarchical structure of the Roman Catholic Church in Italy hinders cooperation and trust of outsiders. Welch et al. (2004), in contrast, claim that, at least since Vatican II, there is no reason to expect that Catholics would trust 'outsiders' any less than mainstream Protestants. They claim that the American Catholic Church is substantially different from the Church in Italy, and that most US Catholic parishes do not maintain a rigid boundary against the outside culture. They further argue that there may well be a difference among Catholics who were socialized into pre-Vatican II traditions relative to the younger group of post-Vatican II Catholics.

Generalizing these various studies, we hypothesize that different religious denominations, or networks, generate different types of social capital and, therefore, that the differing approaches of fundamentalist, moderate and liberal Protestant denominations towards modernization and encroaching secularism will be reflected in differing attitudes of individual members towards others outside the individual's religious network. More specifically, we argue that fundamentalist denominations, on the one hand, are networks that generate Putnam's (2003, p. 23) bonding social capital—or strong in-group loyalty — while generating antagonism towards those outside the fundamentalist network. Liberal and moderate Protestant denominations, on the other hand, are bridging networks that are less threatened by modernization, generate relatively more outward trust, and are less likely to be antagonistic towards outsiders. In addition, the effects of Vatican II are likely to have moderated the bonding-network aspect of Catholicism 
in favour of greater acceptance of those outside the Catholic network.

Theories on social trust are important for understanding the impact of religiosity, or the frequency that an individual participates in a religious network. Delhey and Newton (2002) survey the main schools of thought on social trust. Voluntary Association theory postulates that direct interaction with others on a sustained basis in voluntary organizations builds social trust. Because participation in religious organizations is the predominant form of voluntary association in the United States, religiosity may also condition individuals' attitudes towards trade with others outside the religious network and acceptance of immigrants into their communities. In other words, voluntarily participating in a religious network is likely to generate the bridging type of social capital referred to by Putnam (2000, p. 23), with 'broader identities and reciprocity'. Hence, we hypothesize that individuals who participate more in their respective religious networks, regardless of affiliation, are less likely to favour policies that restrict imports and immigration.

Globalization is one present-day challenge to cultural boundaries forcing an awareness of increasing global connectedness (Pieterse, 2004). Because of this challenge to their traditionalist culture, we suspect that members of fundamentalist denominations are more likely to oppose trade with others and more likely to desire restrictions on immigration, while members of liberal and moderate Protestant denominations are less likely to oppose trade with others and restrictions on immigration. In regard to Catholics, it is possible that changes in Catholic social teaching brought about by Vatican II will be reflected in differences towards trade and immigration policies in that post-Vatican II Catholics are more accepting of those outside their religious network and hence less likely to favour restrictions on trade and immigration. Finally, religiosity may have a different and separate effect than affiliation.

\section{Modelling individual trade and immigration policy preferences}

Recent examinations of trade and immigration-policy preferences focus on two common models of international trade policy preferences: the Ricardo-Viner model and the Heckscher-Ohlin model. Both theories consider the effect of increased trade on input factor returns and provide a framework to explain how individuals evaluate the effect of international trade on their income. Because the literature is extensive, we focus only on the most recent and otherwise refer the interested reader to the surveys provided by Scheve and Slaughter (2001a, b) and Daniels and von der Ruhr (2003).

Scheve and Slaughter employ individual-level survey data for the United States to identify if individual skill level or factor type is a significant determinant of trade-policy preferences. In the 
course of their analysis, they make an important contribution by showing that education, income and employment classification all serve as a proxy measure of skill level. Hence, only one of these variables should be included in any model of trade or immigration policy preferences. Their major finding is that factor type rather than sector of employment influences trade and immigration-policy preferences. Other demographic characteristics, entered as tests of the robustness of factor type, such as gender, race and trade union membership were also found to be significant determinants.

Daniels and von der Ruhr directly extend the analysis of Scheve and Slaughter to 10 advanced economies. Using both education and relative earnings as alternative measure of individual skill level, they find that skill is a robust determinant of individual preferences on immigration policies across countries. In two additional and broader cross-country working papers, Mayda and Rodrik (2001) apply ordered estimation techniques to explain attitudes towards trade and immigration using education as a measure of the individual's level of skill, while O'Rourke and Sinnott (2001) use the individual's occupation classification. Both papers find support for the factor endowment model. Hence, any study of trade and immigration-policy preferences should control for individual skill level.

\section{Survey data}

The data employed in this study are the results of a survey conducted and compiled by Zentralarchiv für Empirische Sozialforschung as the International Social Survey Program (ISSP)

titled ISSP: National Identity. ${ }^{2}$ In the United States, the ISSP is administered as part of the General Social Survey (GSS), but only a subset of the GSS participants are administered the ISSP questionnaire. The combination of both the ISSP and the GSS surveys yield a unique dataset as the 1996 ISSP portion contains questions on imports and immigration while the GSS portion contains, in addition to standard demographic data, detailed information on the individual's religious affiliation and religiosity. Though information on religious affiliation is reported back to the ISSP, the GSS makes much finer distinctions among denominations that are not found in the ISSP data. Because of the uniquely heterogeneous nature of religion in the United States, these distinctions are not available for other countries in the ISSP data and, therefore, we limit our analysis here to residents of the United States.

\subsection{Description of the dependent variables}

The first survey item used in this study asks: 'How much do you agree or disagree with 
the following statement: the United States should limit the import of foreign products in order to protect its national economy?' Five possible responses range from agree strongly to strongly disagree. The second item asks: 'Do you think the number of immigrants to the United States nowadays should be increased or decreased?' Five possible responses range from increased a lot to reduced a lot. Those who could not choose or refused to answer the questions were coded as missing. Table 1 provides the survey items on policy preferences, summarizes the responses and indicates the proportion of missing observations.

\subsection{Description of the independent variables}

Following the literature, we control for a number of factors that may shape an individual's international economic policy preferences. In general, we control for demographics, individual skill level, sector of employment and political ideology, while testing the significance of religious affiliation and religiosity. Each variable is described below and summary data are provided in Table 2.

\section{Demographic variables}

Noncitizen is a dummy variable indicating whether the respondent is a citizen with a value of zero or non-citizen with a value of unity. It is expected that non-citizens are more likely to oppose policies that restrict trade and favour policies that increase immigration. Female is a dichotomous variable that takes the value of unity for female and zero for male. Previous studies find evidence, though not consistently significant, indicating that women are more likely to support trade barriers, but that gender is not a significant determinant of immigration-policy preferences. Age is a continuous variable. It is hypothesized that older respondents are more likely to favour policies that restrict international trade and immigration, though age has not been shown to be a consistently significant determinant of global economic policy preferences.

Social Class is the individual's perspective of their socio-economic status. It is a discrete variable that ranges in value from unity for lower class to six for upper class. South is a dummy variable for the south US Census region. Individuals in the other three regions, therefore, serve as the benchmark for the estimated differential impact of the south. The research on religion and economic growth indicates that a dominant religion affects the culture of a nation and may be the source of cross-country differences in attitudes towards markets and market processes. Hence, if a particular religion dominates a region of a nation, we may see a regional effect that is actually reflecting the influence of the dominant religion along the lines suggested by von der Ruhr and Daniels (2004). Previous research finds that individuals who live in 'gateway' communities — communities that are typical destinations of immigrants—are not more likely to 
oppose immigration.

African American is a dichotomous variable that takes the value of unity if the respondent is African American and zero otherwise. The literature provides mixed evidence on the role of race and ethnicity as determinants of trade and immigration policy preferences. Union Member indicates if the respondent and/ or their spouse is a member of a trade union with a value of unity and zero otherwise. Numerous studies of US residents conclude that trade union members are more likely to favour restricting international trade, but union membership is not a significant determinant of immigration-policy preferences.

\section{Political Ideology}

For a comprehensive discussion of political ideology and attitudes towards globalization see Steger (2002, Ch. 4). Previous studies show that those who identify with the far right are more likely to favour policies that restrict trade and are more likely to favour policies that restrict immigration. Similar to previous studies, we model Political Ideology with a categorical variable that ranges from unity (indicating someone who views their political ideology as far left) to five (indicating someone views their political ideology as far right).

\section{Individual skill level and sector of employment}

Scheve and Slaughter (2001b) show that, if controlling for political ideology and demographic characteristics, education or earnings are appropriate measures of labour market skills and should be included as an economic factor as opposed to a demographic factor. More importantly, they show that education and earnings should not be included in the same model. Because of the number of missing values - 294 for earnings as opposed to 3 for education-we use education as a proxy measure of individual skill throughout the paper. Nonetheless, in general, our results are the same for both education and earnings (available upon request). Education is a continuous variable that indicates the number of years of schooling the respondent has completed. Based on standard trade theory, described earlier, respondents with lower levels of education (skill) are more likely to agree with policy actions that restrict trade and immigration.

Individuals that are employed in sectors at a comparative advantage in the global market may be less likely to favour restrictions on trade and immigration while those employed in sectors at a comparative disadvantage and, therefore, most threatened by trade and immigration, may favour restriction. To control for sector of employment, we follow Mayda and Rodrik (2001, Appendix II), using the adjusted net exports of a sector as an indicator of comparative advantage or disadvantage. First, we use data on the export and import shares of US manufacturing sectors at the two-digit Standard Industrial Classification (SIC) as found in Campa and Goldberg (1997). 
In contrast to Mayda and Rodrik, we also measure the export and import shares of agriculture, forestry and fisheries using data from the US Department of Agriculture, and we proxy for mining, using the export and import shares for the coal industry from the National Mining Association.

We create two dummy variables using the data above in combination with the 1988 Standard Industrial Classification three-digit code contained in the GSS data. The first variable, Comparative Advantage, assigns a value of unity to respondents employed in industries with a positive adjusted net export measure and zero to all others. The second variable, Comparative Disadvantage, assigns unity to individuals in industries with a negative adjusted net export measure and zero to all others. The base group, therefore, is individuals employed all other industries and assumed to be non-trading industries.

\section{Religious affiliation}

The survey instrument asked individuals if they belong to a major religious group. There were approximately 30 denominations the individual could identify with including Catholic, Jewish, Moslem, major Protestant denominations, Shinto, Hindu, Buddhist and Sikh. Individuals were also allowed to select no affiliation or to refuse to answer. In our sample, individuals identified with Catholic, Jewish, Baptist, Methodist, Lutheran, Episcopalian, other Protestant, and two refused to answer and were coded as missing. The frequency of attending religious services, Religiosity, is included in each model containing religious affiliation. This variable ranges from zero for individuals who do not attend at all during the course of a year to eight for those who attend more than once a week.

As previously indicated, the GSS provides additional coding for individuals that took part in the ISSP, allowing much finer distinction of religious affiliation in the United States. The National Opinion Research Center (NORC) provides a classification scheme of Protestant denominations along the fundamentalistmoderate-liberal spectrum, and GSS Methodological Report Number 43 provides details and a complete listing of denominations in their respective categories. According to Smith $(1987,1990)$, the National Opinion Research Center (NORC) framework uses biblical inerrancy, beliefs in the personal salvation or born-again experience, beliefs in the personal and imminent return of Christ, evangelical or revivalist attitudes and acceptance of traditional Protestant beliefs such as the existence of angels and devils, as metrics to separate denominations along the fundamentalist-liberal spectrum. Using this classification system, we re-estimate the empirical models to determine if there are differential effects among Protestant denominations along the fundamentalist to liberal spectrum. 


\subsection{The Second Vatican Council}

The Second Vatican Council represents the most significant change in Catholic doctrine and Catholic social teaching in the past 450 years. Scholars such as Roof and McKinney (1987) and Greeley (1981) document the differences in attitudes among older Catholics and younger Catholics following Vatican II on issues such as premarital sex, divorce and birth control. In addition, the percentage of Catholics attending a parish school declined following Vatican II. Regarding the impact of Vatican II on economic attitudes, Guiso et al. (2002, p. 34) argue that some of the negative impact of Catholicism on economic development no longer exists and that more moderate post-Vatican II Catholicism is not a significant obstacle to economic development. If indeed religious affiliation is an important determinant of individual attitudes, then these important changes should be reflected in the data. Specifically, we expect post-Vatican II Catholics to have more moderate attitudes towards trade and immigration policies.

To investigate a potential Vatican II effect, we follow Guiso et al. (2002) and separate Catholics into two cohort groups, those born before 1962 and those born after, creating a dummy

variable equal to unity if the individual is Catholic and in the particular age-cohort group. To control for a potential generational shift that could be captured by, and attributed to the Vatican II controls for Catholics, we include a dummy variable for all non-Catholics born after 1962. Hence, the control group is all non-Catholics born prior to 1962.

\section{Econometric results}

Our objective is to determine if an individual's religious affiliation holds any additional insight into their trade and immigration-policy preferences. Our approach, therefore, is to add religious affiliation and religiosity to the models of international-policy preferences described earlier, thereby controlling for other important individual demographic, economic and political characteristics. Given that the multiple categories of responses to the survey questions follow a natural order, we use an ordered probit model.

To try to understand the importance of religion, differing denominational effect, interactions with race and the impact of Vatican II, we estimate five different models of each dependent variable. The first model is a base model that allows us to benchmark the results of our data and allow comparison with the literature. The second model adds the individual's major religious affiliation and religiosity. The third model separates Protestants along the fundamentalist to liberal spectrum. The fourth model separates African Americans into two cohort groups; those in a fundamentalist denomination and all other African Americans. ${ }^{6}$ The fifth 
examines the potential impact of Vatican II on Catholic's attitudes towards trade and immigration policies. Because some Protestant denominations are not coded by the NORC into the fundamentalist to liberal scheme, some observations are lost moving from model to model. The number of observations for each model is included at the bottom of each table of results.

\subsection{Attitudes towards International Trade Policies}

Table 3 provides the ordered probit estimates for the survey item on whether the United States should restrict imports. As with other ordered choice models, the magnitudes of the estimated coefficients of the ordered probit models are notoriously difficult to interpret. In this section we discuss those coefficients that are significant. In Section 5.3, we simulate the relative effects of the key variables.

The results of the base model, model 1, indicate that older respondents, respondents residing in the south, African Americans, union members, respondents who identify their political ideology to the right and respondents employed in sectors at a comparative disadvantage are more likely to agree with policies that restrict imports. The base model also indicates that non-residents, respondents who identify their social class to the upper end of the scale and more educated respondents are less likely to agree with policies that restrict imports. Similar to Mayda and Rodrik, employment in a sector with a comparative advantage is not significant.

Model 2 shows that Catholics are more likely to favour policies that restrict imports, but Protestant, Jewish, other religions, as well as religiosity are not significant. Model 3 illustrates the hypothesized difference among Protestant denominations with fundamentalists more likely to favour policies that restrict imports while moderates and liberals are not statistically significantly different from the base group (of individuals that do not profess an affiliation with a religious denomination). Note that in model 3, African American is no longer significant. Hence, in model 4 we separate African Americans into cohorts of those who belong to a fundamentalist denomination and those that do not. (We also remove fundamentalist African Americans from the fundamentalist Protestant group.) Model 4 shows that the typical assumption that African American opposition to free trade is racially based may be incorrect, and that this opposition is driven by religious affiliation, similar to white fundamentalists.

Model 5 separates Catholics into pre-Vatican II and post-Vatican II cohort groups and adds a control for all non-Catholics born after Vatican II. Hence, non-Catholics born prior to Vatican II is the base group for these cohort variables. The results in model 5 show that pre-Vatican II Catholics are more likely to favour policies that restrict imports while post-Vatican II Catholics and all others born after Vatican II are not statistically significantly different from the 
base group.

\subsection{Attitudes towards Immigration Policies}

Table 4 provides the estimates for the immigration models. The estimates for the base model indicate that older respondents, individuals that identify with lower social classes, those who identify their political ideology to the right and lower educated respondents are more likely to support policies that restrict immigration, while non-citizens and African Americans are more likely to favour policies that increase immigration.

Model 2 adds the major religious denominations and the results indicate that Protestants are more likely to support policies that restrict immigration while greater religiosity actually moves individuals to prefer policies that increase immigration. This result for religiosity supports the hypothesis that greater participation in a religious network builds bridging social caption and a broader sense of identity and reciprocity, and that affiliation and religiosity are two separate effects.

Model 3 separates Protestants into moderates, liberals and fundamentalists. The results indicate that the statistically significant result for Protestants is due to fundamentalists favouring restrictions on immigration. The impact of belonging to a fundamentalist denomination is highlighted to a greater degree in model 4, which shows that the result for African Americans pertains only to those not affiliated with a fundamentalist denomination. Finally, model 5 indicates that pre-Vatican II Catholics are more likely to favour policies that restrict immigration while post-Vatican II Catholics and all other post-Vatican II respondents are not. It is important to note, however, that introduction of the post-Vatican II dummy increased the significance level of fundamentalists while making liberal Protestants marginally significant, raising suspicion that there may be a generational effect not fully captured by our models.

\subsection{Interpretation of Model Estimates}

To better understand the impact of religious affiliation on global policy preferences, we simulate the effect of key variables so as to isolate the impact on the probability that an individual chooses one of the responses to the survey questions detailed in Table 1 (along the lines suggested by King et al., 2000). The simulations are conducted using Clarify: Software for Interpreting and Presenting Statistical Results (Tomz et al., 2001). The process involves drawing 1000 simulated parameters from an asymptotic sampling distribution that is multivariate normal, and whose mean is equal to the vector of parameter estimates and variance equal to the 
variance-covariance matrix of estimates. Next, the simulated parameters are used to calculate two sets of probabilities.

Using religious affiliation as an example, we first re-estimate model 5 and then set all binary explanatory variables at their majority value (so that female is equal to one while non-citizen, south, African American, Union Member, Comparative Advantage and Comparative Disadvantage are equal to zero), all denomination variables at zero and the remaining variables at their mean value. In other words, the 'typical' individual in our dataset is treated as if they have no religious affiliation. From this we generate the predicted probability of response to each category of the survey question. Next, we change every individual's affiliation to, say, fundamentalist and repeat the simulation generating new predicted probabilities. To get a sense of the relative importance of religious affiliation, we include the simulated effects of a one standard deviation reduction in education-shown in previous studies as a highly significant determinant of trade and immigration-policy attitudes-as a benchmark. The changes in predicted probabilities for variables of interest are illustrated in Figures 1 and 2.

\section{Policies to restrict imports}

Figure 1 shows the change in predicted probabilities for the five categories of the question on restricting imports for model 5 in Table 3. In general, the figure shows how each variable of interest shifts the distribution of probable responses upward, that is, towards the categories of 'agree strongly' and 'agree' away from the categories of 'neither agree nor disagree', 'disagree' and 'disagree strongly'. The mean value of education is approximately 13.5 years. We change this variable to its 25 th percentile value-approximately 12 years-to obtain the marginal effects of education. Next, education is set at its mean value again and all respondents are coded as fundamentalist and the probabilities are also simulated again. This is then repeated for pre-Vatican II Catholics.

Figure 1 shows that the denominational effects rival that of education, as pre-Vatican II increases the probability that an individual will agree strongly with policies that restrict imports by more than $9.5 \%$ and fundamentalist by more than $7.5 \%$, while a one standard deviation reduction in education (from 1.5 years of post-high-school education to a high-school education) increases this probability by $4.5 \%$. For the category of 'agree', however, the changes are $4.1 \%, 3.7 \%$ and $5.7 \%$, respectively. Nonetheless, the religion effects dominate the education effect in three of the five categories. To present this in another way, education would need to be reduced to 10.5 years (from the mean of 13.5 years) to generate the same impact on attitudes as these two denominational effects. 


\section{Policies to change immigration into the respondent's country}

Figure 2 illustrates the change in the simulated probabilities for the various response categories for education, fundamentalist, pre-Vatican II Catholic and religiosity. As shown in the figure, the pre-Vatican II effect is relatively larger than religiosity and education as the probability that they support policies that reduce immigration a lot increases by $10.9 \%$. If the individual belongs to a fundamentalist denomination, the increase is $10 \%$, and if education is reduced by one-and-one-half years it is $3.6 \%$. The simulation for religiosity represents an increase from the mean value by plus one standard deviation (from attending services roughly one a month to nearly every week). The effect of this increase in religiosity is to decrease the probability that an individual will favour policies that restrict immigration a lot by $2.1 \%$ and to reduce immigration a little by slightly less than $0.5 \%$.

\section{Conclusion}

In this paper we argue that religious affiliation is an important and often neglected force that shapes and reinforces attitudes towards trade and immigration policies. We hypothesize that different religious denominations generate different types of social capital and that the differing approaches of fundamentalist, moderate and liberal Protestant denominations towards modernization and encroaching secularism will be reflected in differing attitudes of individual members towards others outside the individual's religious network. More specifically, we argue that fundamentalist denominations, on the one hand, are networks that generate Putnam's (2003, p. 23) bonding social capital—or strong in-group loyalty—while generating antagonism towards those outside the fundamentalist network. Liberal and moderate Protestant denominations, on the other hand, are bridging networks that are less threatened by modernization, generate relatively more outward trust and are less likely to be antagonistic towards outsiders. In addition, the effects of Vatican II are likely to have moderated the bonding-network aspect of Catholicism in favour of greater acceptance of those outside the Catholic network. Because globalization challenges cultural boundaries and traditionalist culture, we suspect that members of fundamentalist denominations are more likely to oppose trade with others and more likely to desire restrictions on immigration. Furthermore, changes in Catholic social teaching brought about by Vatican II will be reflected in differences towards trade and immigration policies in that post-Vatican II Catholics are likely to be more accepting of those outside their religious network, and hence less likely to favour restrictions on trade and immigration. Finally, religiosity may have a different and separate effect than affiliation effects.

Using the results of a survey of national identity of US residents, we test the impact of 
religious affiliation on trade and immigration-policy preferences while controlling for the individual's level of skill, their political ideology and other important demographic characteristics. Our results show that individuals who are pre-Vatican II Catholic or members of a fundamentalist denomination are more likely to prefer policies that restrict imports and immigration. Furthermore, religiosity has a separate effect of moderating opposition towards immigration. In addition, we find evidence of denominational effects among African Americans in that members of fundamentalist denominations tend to favour policies that restrict imports while others do not, implying that statistical results commonly attributed to racial effects may actually be a religion effect.

Based on our results, we conclude that religion does matter, and that the beliefs produced by specific religious denominations shape public opinion towards trade and immigration thereby representing an important source of resistance to deeper cultural interaction. It is our hope that this paper will motivate greater interest in the subject of religion in the context of international policies. For example, if religion is important to economic performance, what is the process through which religious beliefs eventually move into policy outcomes?

Amstutz (2001) focuses specifically on the role of religion in shaping foreign policy and provides a helpful outline for framing this question. According to Amstutz, there are three ways that religious organizations can affect foreign policy. First, institutions may directly affect foreign policy. In the 1960s, 40\% of members said that their churches should participate in the political process. This grew to more than $50 \%$ by the 1990 s. Hence, there is an exchange between religious leaders and their members that allow religious organizations to lobby (in one way or another) for policy actions. Second, religious organization may also affect foreign policy through ideas. Because religious organizations deal with issues such as equality, just war and subsidiarity, they can help to illuminate and influence perceptions of globalization and facilitate debate on foreign policy issues. As a result, religious values and norms play an indirect, not direct, role in the formation of foreign policy by affecting the attitudes of individuals and thereby shaping public opinion. Finally, because religious organizations provide important humanitarian assistance, they can affect foreign policy through service.

We argue that this second avenue of influence is important for trade and immigration policy decisions, in spite of the fact that there is little in the literature to date that examines the link between religious affiliation and attitudes towards global economic policies. We suggest that future research also consider how the impact of religion on policy preferences is changing across generations of religious adherents. 


\section{Acknowledgements}

Valuable comments and insights were provided by Jim McGibany, participants of the Third Annual Conference on Religion, Economics, and Culture, and two anonymous referees.

\section{Notes}

$\dagger$ Department of Economics, Marquette University, Milwaukee, WI, USA.

‡ Department of Economics, St Norbert College, Cofrin Hall, 100 Grant Street, De Pere, WI, USA.

1. Jubilee 2000-named after the Old Testament concept of Leviticus 25:10 of returning land back to original owners-is an example of the importance of organized religions on global policy.

2. Independent institutions in each country collected the data for the ISSP. Neither the original collectors nor the ZENTRALARCHIV bear any responsibility for the analyses or interpretation presented here.

3. In 1995,1367 of the 2904 GSS respondents were administered the ISSP questionnaire.

4. This difference is consistent with union positions on these two issues. For example, the AFL-CIO 'Agenda For All America' (AFL-CIO, 2002) item (2) is 'Keep good jobs and level the playing field. In the past year alone, more that one million manufacturing jobs have fallen victim to flawed trade policies and inadequate protections for workers in the global economy. We must develop an effective strategy and programme for stopping the exports of good jobs and reindustrializing the US economy'. While John Sweeney (AFL-CIO, 2000), speaking on the Restoration of Fairness in Immigration Act stated: 'The AFL-CIO proudly stands on the side of immigrant workers. Throughout the history of this country, immigrants have played an important role in building our nation and its democratic institutions'.

5. To test the sensitivity of these results to the year that was picked for constructing the dummy variables, we moved the year ahead five years and back five years and our results were consistent in terms of sign and significance.

6. This grouping separates the 186 African Americans in the sample into 110 in fundamentalist denominations and 76 who are not in fundamentalist denominations.

7. Following the estimation of model 5 of both the trade question and the immigration question, we simultaneously test for pairwise equality and joint significance of the denomination dummies. (The test statistic is a $X^{2}$.) For the trade model, the null of pairwise 
equality and jointly equal to zero is rejected with a P-value of $2.39 \%$, and for the immigration model the null is rejected with a P-value of $1.05 \%$, indicating that there is difference among the denomination coefficients and that they are jointly significantly different from zero.

\section{References}

AFL-CIO (2000) 'Statement by John J. Sweeney, AFL-CIO President on The Restoration of Fairness in Immigration Act of 2000', available at http://www.aflcio.org.

AFL-CIO (2002) 'An Agenda For All America: Good Jobs, Strong Communities, Corporate Accountability', available at http://www.aflcio.org.

Amstutz, M. R. (2001) 'Faith-Based NGO's and U.S. Foreign Policy'. In Abrams, E. (ed.) The Influence of Faith: Religious Groups and U.S. Foreign Policy, New York, Rowman and Littlefield, pp. 175-188.

Ammerman, N. T. (1991) 'North American Protestant Fundamentalism'. In Marty, M. and Appleby, R. (eds) Fundamentalism Observed, Chicago, Chicago University Press, pp. $1-65$.

Barro, R. J. and McCleary, R. M. (2003) 'Religion and Political Economy in an International Panel', American Sociological Review, 68, 760-81.

Campa, J. and Goldberg, L. S. (1997) 'The Evolving External Orientation of Manufacturing: A Profile of Four Countries', Federal Reserve Bank of New York, Economic Policy Review, 3(2), 53-81.

Coreno, T. (2002) 'Fundamentalism as a Class Culture', Sociology of Religion, 63(3), 335-60.

Daniels, J. P. and von der Ruhr, M. (2003) 'The Determinants of Immigration-Policy Preferences in Advanced Economies: A Cross-Country Study', Atlantic Economic Journal, 31(2), $146-58$.

Dark, K. R. (2000) Religion and International Relations, New York, St Martin's Press, Inc.

Delhey, J. and Newton, K. (2002) 'Who Trusts? The Origins of Social Trust in Seven Nations,' Social Science Research Center, Berlin.

Financial Times (2004) "Southern Democrat Avoids Saying 'Kerry", 14 May, p. 4.

Foreign Policy (2004) 'Keeping the Faith', March/April, pp. 62-3. Gay, C. M. (1991) With Liberty and Justice for Whom? The Recent Evangelical Debate over Capitalism, Grand Rapids, William B. Eearmans Publishing Company.

Graham, T. W. (1994) 'Public Opinion and U.S. Foreign Policy Decision Making', In Deese, D. A. (ed.) The New Politics of American Foreign Policy, New York, St Martin's Press Inc., pp. 190-215. 
Greeley, A. M. (1981) The Religious Imagination, Los Angeles, William H. Sadlier.

Grossman, G. M. and Helpman, E. (2000) Special Interest Politics, Cambridge, MA, MIT Press.

Guiso, L., Sapienza, P. and Zingales, L. (2003) ‘People’s Opium? Religion and Economic Attitudes', Journal of Monetary Economics, 50(1), 225-82.

lannaccone, L. R. (1998) 'Introduction to the Economics of Religion', Journal of Economic Literature, XXXVI, 1465-96.

King, G., Tomz, M. and Wittenberg, J. (2000) 'Making the Most of Statistical Analyses: Improving Interpretation and Presentation', American Journal of Political Science, 44(2), 347-61.

Marsden, G. M. (1991) Understanding Fundamentalism and Evangelicalism, Grand Rapids, MI, W.B. Eerdmans.

Mayda, A. M. and Rodrik, D. (2001) 'Why are Some People (and Countries) More Protectionist than Others?' Draft Paper, Harvard University.

Mehanna, R.-A. (2002) 'International Trade, Religion, and Political Freedom: An Empirical Examination', Wartburg College.

Milner, H. V. (1988) Resisting Protectionism: Global Industries and the Politics of International Trade, Princeton, Princeton University Press.

O'Rourke, K. H. and Sinnott, R. (2001) 'The Determinants of Individual Trade Policy Preferences: International Survey Evidence', Working Paper.

Philpott, D. (2002) 'The Challenge of September 11 to Secularism in International Relations', World Politics, 55, 66-95.

Pieterse, J. N. (2004) Globalization and Culture: Global Mélange, Lanham, MA, Rowman and Littlefield.

PIPA (2000) 'Americans on Globalization: A Study of US Public Attitudes'; Program on International Policy Attitudes, 28 March.

Putnam, R. D. (2000) Bowling Alone: The Collapse and Revival of American Community, New York, Simon and Schuster.

Putnam, R. D., Leonardi, R. and Nanetti, R. U. (1993) Making Democracy Work: Civic Tradition in Modern Italy, Princeton, Princeton University Press.

Putnam, R. D., Feldsten, L. M. and Cohen, D. (2003) Better Together: Restoring the American Community, New York, Simon and Schuster.

Roof, W. C. and McKinney, W. (1987) American Mainline Religion: Its Changing Shape and Future, New Brunswick, Rutgers University Press.

Scheve, K. F. and Slaughter, M. J. (2001a) 'What Determines Individual Trade-Policy Preferences?', Journal of International Economics, 54, 267-92. 
Scheve, K. F. and Slaughter, M. J. (2001b) 'Labor Market Competition and Individual Preferences over Immigration Policy', The Review of Economics and Statistics, 83(1), 133-45.

Smith, T. W. (1987) 'Classifying Protestant Denominations', General Social Survey Methodological Report No. 43, ICPSR, University of Michigan.

Smith, T. W. (1990) 'Classifying Protestant Denominations', Review of Religious Research, 31, 225-45.

Smith, I. and Sawkins, J. W. (1998) 'The Economics of Religious Participation: A Cross-Country Study', Kyklos, 51(1), 25-44.

Steger, M. B. (2002) Globalism: The New Market Ideology, Lanham, Maryland, Rowman and Littlefield Publishers Inc.

Tamney, J. B. (2002) The Resilience of Conservative Religion: The Case of Popular, Conservative Protestant Congregations, New York, Cambridge University Press.

Tomz, M., Wittenberg, J. and King, G. (2001) 'CLARIFY: Software for Interpreting and Presenting Statistical Results, Version 2.0', Cambridge, MA, Harvard University, available at http://gking.harvard.edu.

von der Ruhr, M. and Daniels, J. P. (2003) 'The Relationship Between Religious Affiliation, Region, Race, and Attitudes Toward Globalization', Faith and Economics, 42, 26-39.

Welch, P. J. and Mueller, J. J. (2001) 'The Relationships of Religion to Economics', Review of Social Economy, VLIX(2), 185-202.

Welch, M. R., Sikkink, D., Sartain, E. and Bond, C. (2004) 'Trust in God and Trust in Man: The Ambivalent Role of Religion in Shaping Dimensions of Social Trust', Journal for the Scientific Study of Religion, 43(3), 317-43. 


\section{Appendix}

\section{Table 1: Summary of dependent variables}

How much do you agree or disagree with the following statement: the United States should limit the import of foreign products in order to protect its national economy

Response 1

Response 2

Response 3

Response 4

Response 5

Response 6

Mean response

Standard error of the mean

Number of respondents

Observations

Missing
Agree strongly

Agree

Neither agree nor disagree

Disagree

Strongly disagree

Cannot choose, refused

2.2589

0.0282

1367

1290

77

Do you think the number of immigrants to the United States nowadays should be

\section{Response 1}

Response 2

Response 3

Response 4

Response 5

Response 6

Mean response

Standard error of the mean

Number of respondents

Number of observations

Missing
Increased a lot Increased a little Remain the same Reduced a little Reduced a lot Cannot choose, refused 3.8715

0.0330 1367

226 
Table 2: Summary statistics on independent variables

\begin{tabular}{|c|c|c|c|c|c|c|c|}
\hline Variable & Observations & Missing & Number $=1$ & Mean & SD & Minimum & Maximum \\
\hline Noncitizen & 1342 & 25 & 52 & 0.0416971 & 0.1999694 & 0 & 1 \\
\hline Female & 1367 & 0 & 772 & 1.56474 & 0.4959724 & 1 & 2 \\
\hline Age & 1363 & 4 & NA & 44.50183 & 16.56635 & 18 & 89 \\
\hline Social Class & 1357 & 10 & NA & 2.453943 & 0.657592 & 1 & 4 \\
\hline South & 1367 & 0 & 467 & 0.341624 & 0.4744278 & 0 & 1 \\
\hline African American & 1367 & 0 & 186 & 0.1360644 & 0.3429824 & 0 & 1 \\
\hline Fundamentalist & 1365 & 2 & 110 & 0.0804682 & 0.2721162 & 0 & 1 \\
\hline All others & 1365 & 2 & 76 & 0.0555962 & 0.2292241 & 0 & 1 \\
\hline Union member & 1361 & 6 & 180 & 0.1316752 & 0.3382611 & 0 & 1 \\
\hline Political ideology & 1299 & 68 & NA & 4.149346 & 1.364594 & 1 & 7 \\
\hline Education & 1364 & 3 & NA & 13.42375 & 2.875641 & 0 & 20 \\
\hline Comparative advantage & 1360 & 7 & 270 & 0.1985294 & 0.3990396 & 0 & 1 \\
\hline Comparative disadvantage & 1360 & 7 & 54 & 0.0397059 & 0.1953391 & 0 & 1 \\
\hline Protestant & 1365 & 2 & 794 & 0.5808339 & 0.4936032 & 0 & 1 \\
\hline Moderate & 1365 & 2 & 181 & 0.1324067 & 0.3390565 & 0 & 1 \\
\hline Liberal & 1365 & 2 & 190 & 0.1389905 & 0.3460632 & 0 & 1 \\
\hline Fundamentalist & 1365 & 2 & 413 & 0.3021214 & 0.4593456 & 0 & 1 \\
\hline Catholic & 1365 & 2 & 318 & 0.2326262 & 0.4226605 & 0 & 1 \\
\hline Pre-Vatican II Catholic & 1365 & 2 & 204 & 0.1316752 & 0.3382611 & 0 & 1 \\
\hline Post-Vatican II Catholic & 1365 & 2 & 114 & 0.100951 & 0.3013741 & 0 & 1 \\
\hline Post-Vatican II all others & 1365 & 2 & 371 & 0.2713972 & 0.4448433 & 0 & 1 \\
\hline Jewish & 1365 & 2 & 32 & 0.0234089 & 0.1512537 & 0 & 1 \\
\hline Other religion & 1365 & 2 & 67 & 0.0490124 & 0.215973 & 0 & 1 \\
\hline Religiosity & 1325 & 42 & NA & 3.707925 & 2.652589 & 0 & 8 \\
\hline
\end{tabular}

Daniels, von der Ruhr 21 
Table 3: The United should limit the import of foreign products: ordered probit results

\begin{tabular}{|c|c|c|c|c|c|}
\hline & Model 1 & Model 2 & Model 3 & Model 4 & Model 5 \\
\hline Noncitizen & $0.422[0.164]^{\star * *}$ & $0.436[0.166]^{* * *}$ & $0.416[0.166]^{* *}$ & $0.418[0.166]^{* *}$ & $0.375[0.168]^{\star *}$ \\
\hline Female & $-0.106[0.066]$ & $-0.109[0.067]$ & $-0.114[0.068]^{*}$ & $-0.115[0.068]^{*}$ & $-0.113[0.068]^{\star}$ \\
\hline Age & $-0.004[0.002]^{\star}$ & $-0.004[0.002]^{\star}$ & $-0.005[0.002]^{\star *}$ & $-0.005[0.002]^{* *}$ & $-0.003[0.003]$ \\
\hline Social Class & $0.145[0.052]^{* * *}$ & $0.145[0.053]^{* * *}$ & $0.14[0.053]^{\star * *}$ & $0.141[0.053]^{* * *}$ & $0.139[0.053]^{* * *}$ \\
\hline South & $-0.241[0.068]^{\star \star \star}$ & $-0.261[0.072]^{* * *}$ & $-0.236[0.072]^{\star \star \star}$ & $-0.238[0.073]^{\star * *}$ & $-0.236[0.073]^{\star \star *}$ \\
\hline African American & $-0.193[0.099]^{* *}$ & $-0.18[0.101]^{\star}$ & $-0.149[0.103]$ & & $-0.141[0.103]$ \\
\hline Fundamentalist & & & & $-0.5[0.162]^{* * *}$ & \\
\hline All Others & & & & $-0.048[0.152]$ & \\
\hline Union member & $-0.463[0.094]^{* * *}$ & $-0.483[0.097]^{* * *}$ & $-0.493[0.097]^{* * *}$ & $-0.498[0.097]^{* * *}$ & $-0.48[0.097]^{* * *}$ \\
\hline Political ideology & $-0.091[0.023]^{* * *}$ & $-0.094[0.024]^{* * *}$ & $-0.091[0.024]^{* * *}$ & $-0.093[0.025]^{* * *}$ & $-0.09[0.024]^{* * *}$ \\
\hline Education & $0.107[0.013]^{\star * *}$ & $0.106[0.013]^{\star * *}$ & $0.105[0.013]^{\star * *}$ & $0.105[0.013]^{\star * *}$ & $0.107[0.013]^{* \star *}$ \\
\hline Comparative advantage & $-0.077[0.083]$ & $-0.099[0.086]$ & $-0.097[0.086]$ & $-0.095[0.086]$ & $-0.089[0.086]$ \\
\hline Comparative disadvantage & $-0.31[0.176]^{*}$ & $-0.3[0.181]^{\star}$ & $-0.306[0.181]^{\star}$ & $-0.297[0.181]$ & $-0.299[0.181]^{\star}$ \\
\hline Protestant & & $-0.172[0.117]$ & & & \\
\hline $\begin{array}{l}\text { Moderate } \\
\text { Liberal }\end{array}$ & & & $\begin{array}{l}-0.065[0.136] \\
-0.147[0.132]\end{array}$ & $\begin{array}{r}-0.07[0.136] \\
-0.144[0.132]\end{array}$ & $\begin{array}{r}-0.08[0.136] \\
-0.162[0.133]\end{array}$ \\
\hline Fundamentalist & & & $-0.3[0.124]^{* *}$ & $-0.269[0.129]^{* *}$ & $-0.311[0.124]^{* *}$ \\
\hline Catholic & & $-0.28[0.123]^{* *}$ & $-0.299[0.120]^{* *}$ & $-0.295[0.120]^{* *}$ & \\
\hline Pre-Vatican II Catholic & & & & & $-0.385[0.136]^{* * *}$ \\
\hline Post-Vatican II Catholic & & & & & $-0.125[0.165]$ \\
\hline Post-Vatican II all others & & & & & $0.045[0.108]$ \\
\hline Jewish & & $0.006[0.238]$ & $-0.004[0.236]$ & $-0.001[0.236]$ & $-0.012[0.237]$ \\
\hline Other religion & & $0.028[0.177]$ & $0.011[0.175]$ & $0.013[0.175]$ & $0.011[0.175]$ \\
\hline Religiosity & & $0.013[0.014]$ & $0.017[0.014]$ & $0.016[0.014]$ & $0.017[0.014]$ \\
\hline Observations & 1208 & 1174 & 1174 & 1174 & 1174 \\
\hline
\end{tabular}


Table 4: The number of immigrants to the United States should be ordered probit results

\begin{tabular}{|c|c|c|c|c|c|}
\hline & Model 1 & Model 2 & Model 3 & Model 4 & Model 5 \\
\hline Noncitizen & $-0.676[0.169]^{* * *}$ & $-0.611[0.171]^{* * *}$ & $-0.605[0.171]^{* * *}$ & $-0.605[0.171]^{* * *}$ & $-0.501[0.174]^{* * *}$ \\
\hline $\begin{array}{l}\text { Female } \\
\text { Age }\end{array}$ & $\begin{array}{c}0.11[0.069] \\
0.006[0.002]^{* * *}\end{array}$ & $\begin{array}{l}0.097[0.071] \\
0.005[0.002]^{\star *}\end{array}$ & $\begin{array}{l}0.101[0.071] \\
0.005[0.002]^{* *}\end{array}$ & $\begin{array}{l}0.102[0.071] \\
0.005[0.002]^{\star *}\end{array}$ & $\begin{array}{r}0.1[0.071] \\
0.004[0.003]\end{array}$ \\
\hline Social Class & $-0.158[0.055]^{* * *}$ & $-0.147[0.056]^{* * *}$ & $-0.145[0.056]^{* * *}$ & $-0.146[0.056]^{* * *}$ & $-0.148[0.056]^{* * *}$ \\
\hline South & $0.07[0.073]$ & $0.036[0.076]$ & $0.035[0.077]$ & $0.038[0.077]$ & $0.038[0.077]$ \\
\hline African American & $-0.236[0.106]^{* *}$ & $-0.265[0.110]^{* *}$ & $-0.272[0.111]^{* *}$ & & $-0.283[0.111]^{* *}$ \\
\hline Fundamentalist & & & & $0.023[0.173]$ & \\
\hline All others & & & & $-0.371[0.167]^{* *}$ & \\
\hline Union member & $0.017[0.099]$ & $0.012[0.101]$ & $0.018[0.101]$ & $0.02[0.101]$ & $0.002[0.102]$ \\
\hline Political ideology & $0.076[0.025]^{* * *}$ & $0.078[0.026]^{* * *}$ & $0.079[0.026]^{* * *}$ & $0.081[0.026]^{* * *}$ & $0.078[0.026]^{* * *}$ \\
\hline Education & $-0.045[0.013]^{* * *}$ & $-0.044[0.013]^{* * *}$ & $-0.044[0.014]^{* * *}$ & $-0.044[0.014]^{* * *}$ & $-0.046[0.014]^{* * *}$ \\
\hline Comparative advantage & $-0.079[0.086]$ & $-0.109[0.089]$ & $-0.104[0.089]$ & $-0.105[0.089]$ & $-0.124[0.089]$ \\
\hline Comparative disadvantage & $-0.199[0.185]$ & $-0.191[0.192]$ & $-0.188[0.192]$ & $-0.202[0.193]$ & $-0.209[0.192]$ \\
\hline Protestant & & $0.301[0.126]^{* *}$ & & & \\
\hline Moderate & & & $0.171[0.144]$ & $0.175[0.145]$ & $0.217[0.145]$ \\
\hline Liberal & & & $0.203[0.141]$ & $0.201[0.141]$ & $0.258[0.142]^{*}$ \\
\hline Fundamentalist & & & $0.266[0.132]^{\star}$ & $0.260[0.136]^{*}$ & $0.275[0.132]^{\star \star}$ \\
\hline Catholic & & $0.108[0.131]$ & $0.036[0.127]$ & $0.031[0.127]$ & \\
\hline Pre-Vatican II Catholic & & & & & $0.296[0.144]^{* *}$ \\
\hline Post-Vatican II Catholic & & & & & $-0.217[0.174]$ \\
\hline Post-Vatican II all others & & & & & $0.114[0.116]$ \\
\hline Jewish & & $-0.214[0.244]$ & $-0.285[0.242]$ & $-0.288[0.242]$ & $-0.235[0.242]$ \\
\hline Other religion & & $0.137[0.193]$ & $0.067[0.190]$ & $0.066[0.190]$ & $0.082[0.190]$ \\
\hline Religiosity & & $-0.03[0.015]^{* *}$ & $-0.028[0.015]^{\star}$ & $-0.028[0.015]^{\star}$ & $-0.029[0.015]^{* *}$ \\
\hline Observations & 1081 & 1049 & 1049 & 1049 & 1049 \\
\hline
\end{tabular}


Figure 1: US should restrict imports

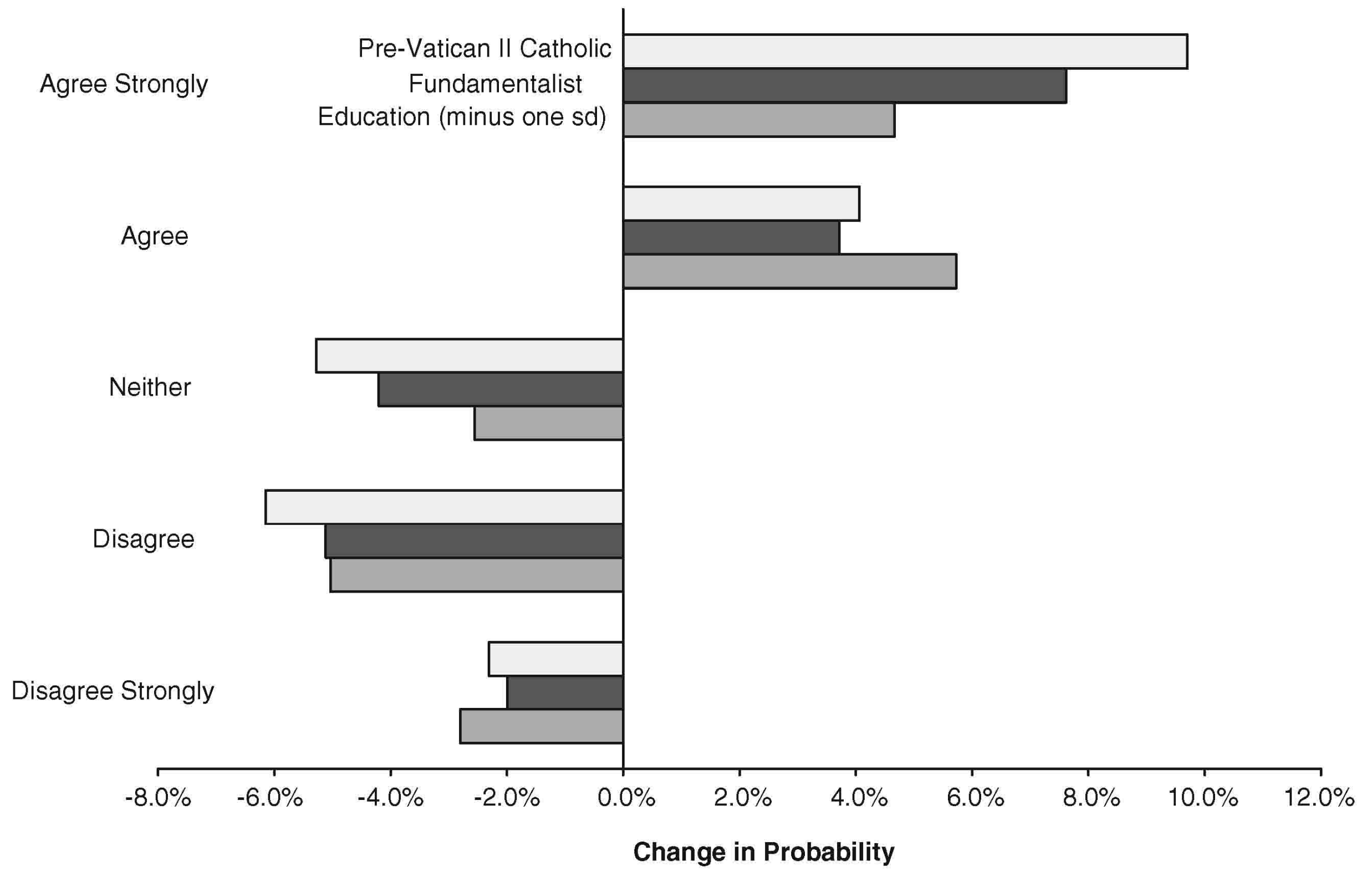


Figure 2: The number of immigrants

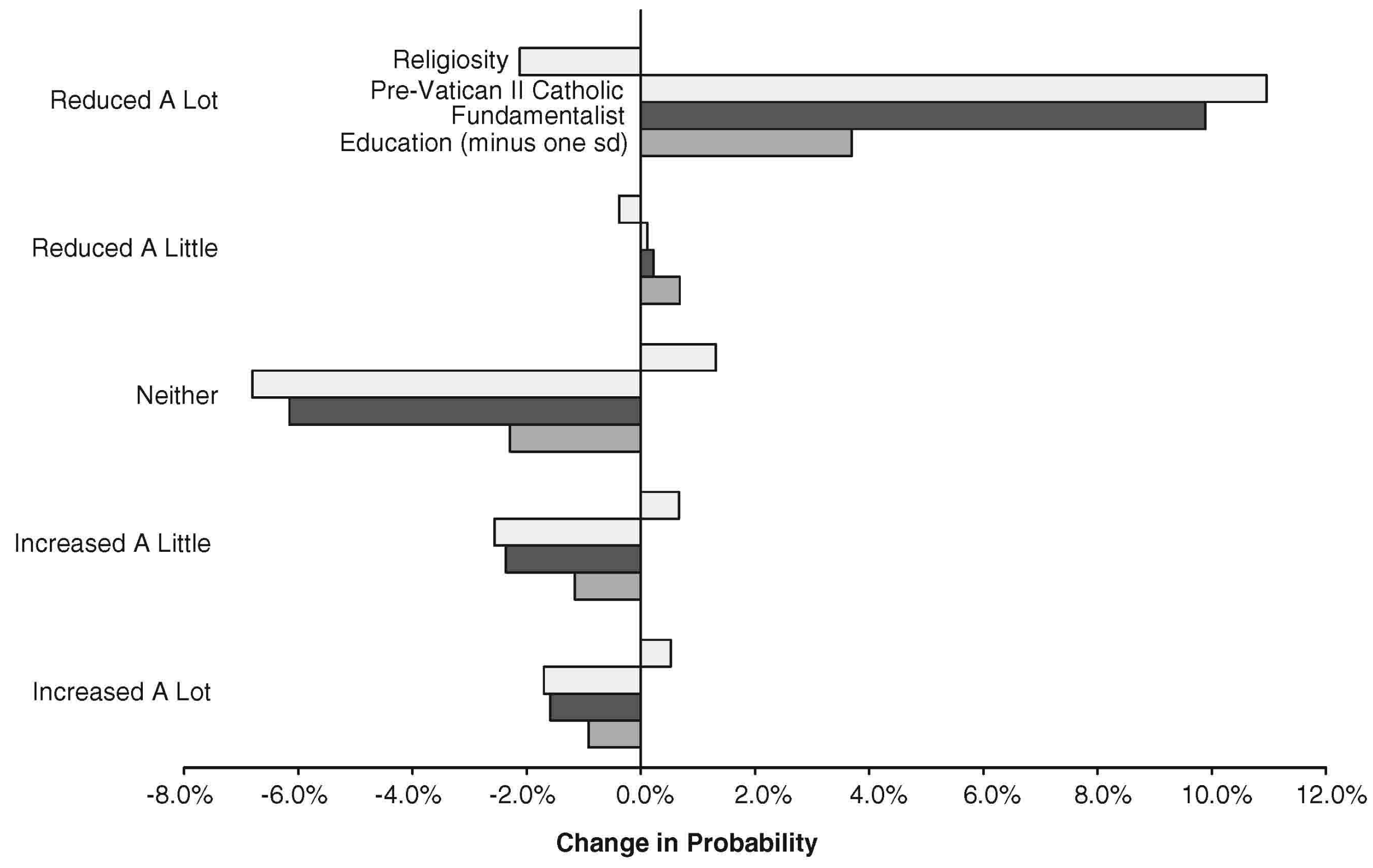

